\title{
On the Nematocysts of Sea Anemones.
}

\author{
By \\ T. A. Stephenson, D.Sc., \\ Zoology Department, University College, London.
}

With 1 Plate and 10 Figures in the Text.

CONTENTS.

INTRODUCTION

1. Material and Methods . . . . . . . . . . . . . . . . . 173

2. Account of the Observations made . . . . . . . . . 175

A. Variability of the Capsules within a single species . $\quad . \quad . \quad . \quad . \quad 178$

B. Connection between the Size of the Animal and the Size of the Nematocysts 179

C. The Nematocysts in the Acontia of the Species of Sagartia . . . 180

D. The Nematocysts in the Acontia of other Genera . . . . . . 184

E. The Nematocysts of Tissues other than Acontia . . . . . . $\quad 185$

F. Other Data . . . . . . . . . . . . . . . . 186

3. Summary and Conclusions . . . . . . . . . . . . . . . 187

Tables . . . . . . . . . . . . . . . . . . . . . . . . . . 192

Literature . . . . . . . . . . . . . . . . . . . . . . . . . . . . 198

Explanation of Plate . . . . . . . . . . . . . . 200

\section{INTRODUCTION.}

THE main object of this paper has been to determine whether or no it is possible to differentiate the species and genera of Actinians by employing as criteria the characteristics of their nematocysts.

I wish to acknowledge that I have received a grant from the Royal Society which has very greatly assisted the work described. The figures in Plate I have been published before in my Ray Society monograph on the British anemones; but their repetition here is essential for the adequate illustration of this paper. Figs. 1 and 4 on this plate are copied from Will's paper on spirocysts (1909a, Pl. 3, Figs. 4 and 9).

\section{MATERIAL AND METHODS.}

The material for this study was mostly obtained at Plymouth, this being supplemented by specimens from other places where necessary. The whole of the observations apply to fresh material studied before fixation, unless otherwise stated.

The object of the research was to take measurements of the capsules of nematocysts and to make observations on the distribution of the 
different patterns of nematocyst among various species; for this purpose it was not necessary to make permanent preparations, and such were not attempted.

When the nematocysts to be studied are contained in an acontium belonging to a species which emits acontia readily, or when they are situated in a tentacle, it is easy to isolate a small piece of one of these tissues for study. Similarly, if a sample of nematocysts from the bodywall be required, a small amount of ectoderm containing them can readily be scraped off. If, however, nematocysts are required from the mesenterial filaments, throat, peristome, acrorhagi, etc., it is advisable to anæsthetise the anemone with menthol, until it ceases to respond to tactile stimuli. It can then be cut up without undue contraction, and accurate samples of the tissues required may be extracted.

For purposes of measurement and general observation fresh preparations of nematocysts may usually be employed without staining. In certain cases, however, and for the observation of particular details, these preparations may be stained directly. The best stains for general purposes are methylene blue (a 1\% solution, or weaker) and acid fuchsin $(1 \%)$. Spirocysts have a strong affinity for acid fuchsin, and some kinds of nematocysts, or perhaps all nematocysts under given conditions, for methylene blue-and it is possible to stain a preparation containing both so that the spirocysts appear bright crimson, and the nematocysts deep blue ; usually, however, the stains are employed separately. I have tried various other stains-picronigrosin, hæmatoxylin, eosin, picroindigo-carmine, methyl green, neutral red, Janus green, etc. Some of these are useful for staining nematocysts or spirocysts in sections, but for fresh material nothing I have used equals the methylene blue and fuchsin; other workers have found the same. In some cases the details of the barbs and spirals on the threads of the nematocysts can be seen to more advantage by introducing them into a medium of high refractive index. A medium which I have found serviceable is one described by Lee (Microtomist's Vade-mecum, 1921 Edition, p. 224)-a saturated solution of potassium iodide and biniodide of mercury in distilled water. The solution is made by grinding up the two materials together with a little water in a small mortar ; the amount of these which dissolves in a small quantity of water is considerable, and a syrupy solution of a clear greenish yellow colour results. This solution can be either used at full strength or in various dilutions, according to the index required. When adding it to a fresh preparation it is best to acclimatise this by introducing a drop of a dilute solution before a higher concentration is used. The action of methylene blue for the demonstration of detail is altered and sometimes enhanced by the addition of a very little potassium hydroxide (in a $5 \%$ or $10 \%$ solution) to the preparation. If the mercury 
medium is also employed, this should be added after the $\mathrm{KOH}$ and methylene blue, which may with advantage be mixed (provided proper proportions are used) immediately before they are added to the preparation. The results with such preparations are sometimes excellent, but very transitory.

Fresh preparations are made as follows. A small piece of the tissue to be studied is placed on a slide in a drop of sea-water. It is chopped into very fine fragments with a small needle-knife. All fragments are then eliminated save those of the finest grade, and a cover-slip is added. The cover-slip should be a large one, almost completely covering the slide, and the drop of fluid beneath it should be small. This ensures that the film between slide and cover-slip shall be very thin, so that the cover-slip is held tightly down. Consequently the nematocysts in the preparation do not move about in the fluid; they cannot, of course, be measured unless they are perfectly stationary. After the addition of the cover-slip, the preparation may be further dissociated by holding the slip down at one corner, between finger and thumb, and rubbing its surface firmly with the blunt end of a small scalpel, especially over the spots where little masses of tissue occur. In good preparations of this nature there should be many isolated nematocysts both exploded and otherwise, free from surrounding tissue. The smaller the amount of tissue used the bettersometimes it is enough to rub a fragment of tissue in a drop of water on a slide, remove the tissue, and use the nematocysts left in the drop. Larger masses of tissue, dissociated by being firmly pressed out, are useful for certain purposes, but not if one desires to see detail in the capsules. The method here outlined is not a refined one, but quite adequate for the object in view.

The microscope employed for the work was a Leitz binocular, with interchangeable binocular and monocular body (the monocular being used for measuring). It was used with a thorium-lamp, achromatic condenser, and a bull's-eye between the lamp and the mirror. Various objectives (oilimmersions) and eye-pieces, including compensating-oculars, were tried, but for general purposes it was found that No. 2 eye-pieces and a 10 water-immersion objective (Leitz) gave the best results.

\section{ACCOUNT OF THE OBSERVATIONS MADE.}

The measurements recorded below were made with a Leitz eye-piecemicrometer, No. 2 eye-piece, and 10 water-immersion objective (very rarely a $\frac{1}{12}$ inch oil-immersion).

A cnida, be it a nematocyst or a spirocyst (see p. 187 for further details), consists of a hollow refringent capsule, with one end of which a hollow thread is continuous. The thread is inside the capsule before explosion takes place, outside afterwards; and in changing from one 


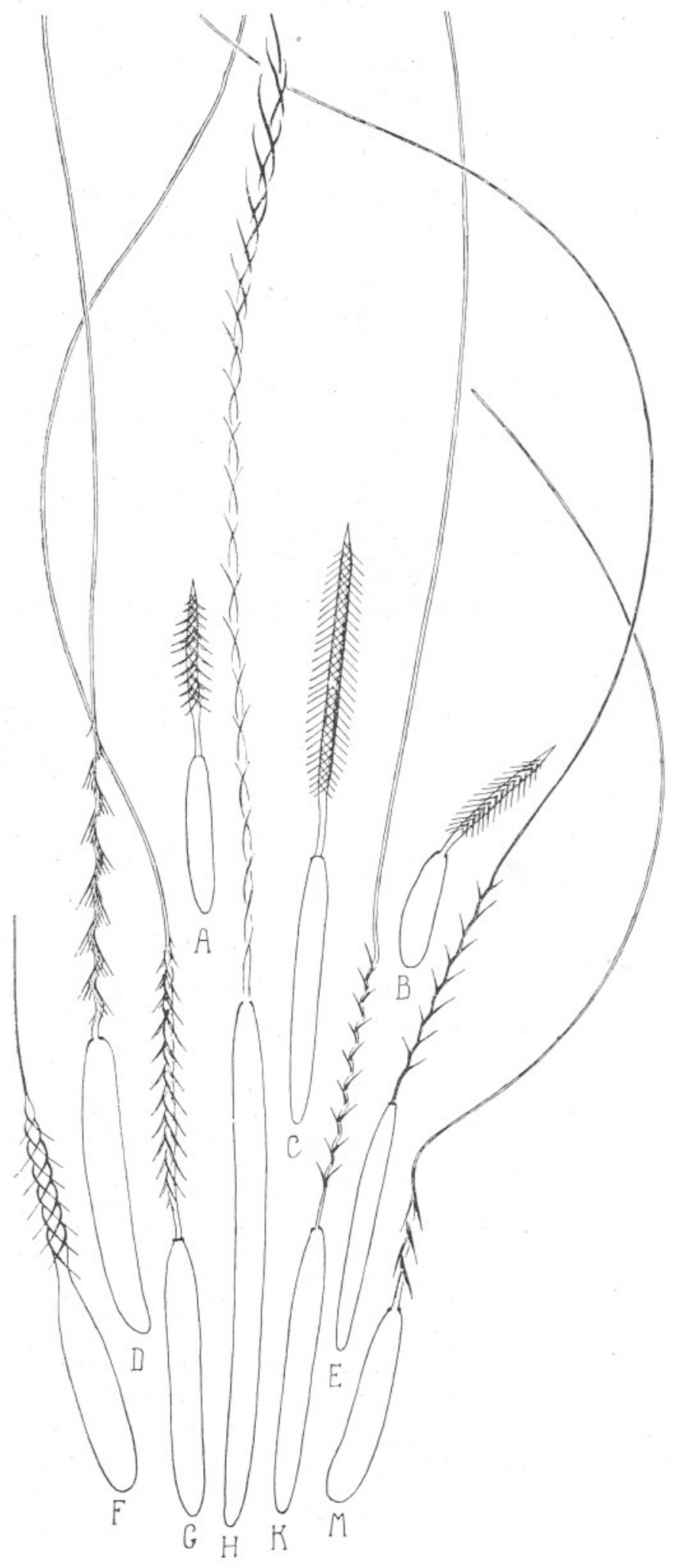


position to the other it evaginates or turns completely inside out, as one may turn a glove-finger. The dimensions of the capsule are less variable and much easier to obtain than those of the thread, and are therefore taken as the standard of size.

All the measurements given below, therefore, refer to the capsule, measured on fresh preparations in sea-water (unless otherwise stated), unstained and free from reagents, so that no distortion of the natural dimensions has been introduced. The capsules were measured after the eversion of the thread, wherever possible, because it is always easier to recognise the pattern of a capsule after evagination than before, and thus one avoids any question of confusing two similar kinds. In certain cases, however, the capsules seem to explode reluctantly, and a large proportion of evaginated specimens cannot be obtained without the use of reagents ; in such cases they were measured unexploded. In these instances, of course, care was taken to ascertain the exact appearance of the type of capsule in question both before and after evagination, so that no question of confusing types is involved. The latter becomes more important in dealing with fixed material. In the tables on pages 192-198, therefore, the measurements are on exploded capsules, unless otherwise stated. A comparison of exploded and unexploded nematocysts will be found on page 198. The margin of error in the measurements is probably very slight as regards the length of the capsule, but greater in the case of the breadth, which must be regarded as approximate. The number of samples of any one tissue examined was usually 2 or 3 , sometimes more ; a single sample was used only in cases where very little material was available.

It should be noted that all the statements in this paper refer to the types of nematocysts which predominate in any tissue. In many cases there exist, in one and the same tissue, majority-forms and minorityforms. The latter are usually smaller than the former, and although they are sometimes rather numerous, they are generally present in much smaller numbers than the majority-forms. It is difficult to estimate their numbers and importance, and also to make out their structure, and in the present study they have been left out of account. In adequate fresh preparations there is no difficulty in determining which are the majorityforms.

Text-Fig. 1.-Sketches showing the general appearance of some Actinian nematocysts (for more detailed drawings see PI. I). Figs. A, B, C, and F are penicilli of different varieties; the others are spirulæ, their barbs erect in some cases, reversed in others. Fig. H (Metridium) is a spirula, but only the enlarged basal part of the thread is shown, this part being unusually long here. A, Sagartia troglodytes var. ornata (acontium) ; B, Phellia gausapata (tentacle); C and K, Phellia gausapata (acontium) ; D and G, Gephyropsis dohrnii (acontium), two nematocysts of the same kind in different conditions; E, Paraphellia expansa (acontium); F, Peachia triphylla (mesenterial filament); H, Metridium senile (acontium); M, Peachia triphylla (throat).

NEW SERIES.-VOL. XVI. NO. 1. MAY, 1929. 


\section{A. Variability of the Capsules within a single Species.}

The first step was to gain some idea of the degree to which the size of the capsule varies in a single tissue of one and the same species. For this purpose a variable species (Sagartia elegans) was chosen, and the nematocysts from the acontia of specimens from different localities (Plymouth and Valencia) were studied. Twelve specimens were used, belonging to various colour-varieties (venusta, venustoides, nivea, niveoides,

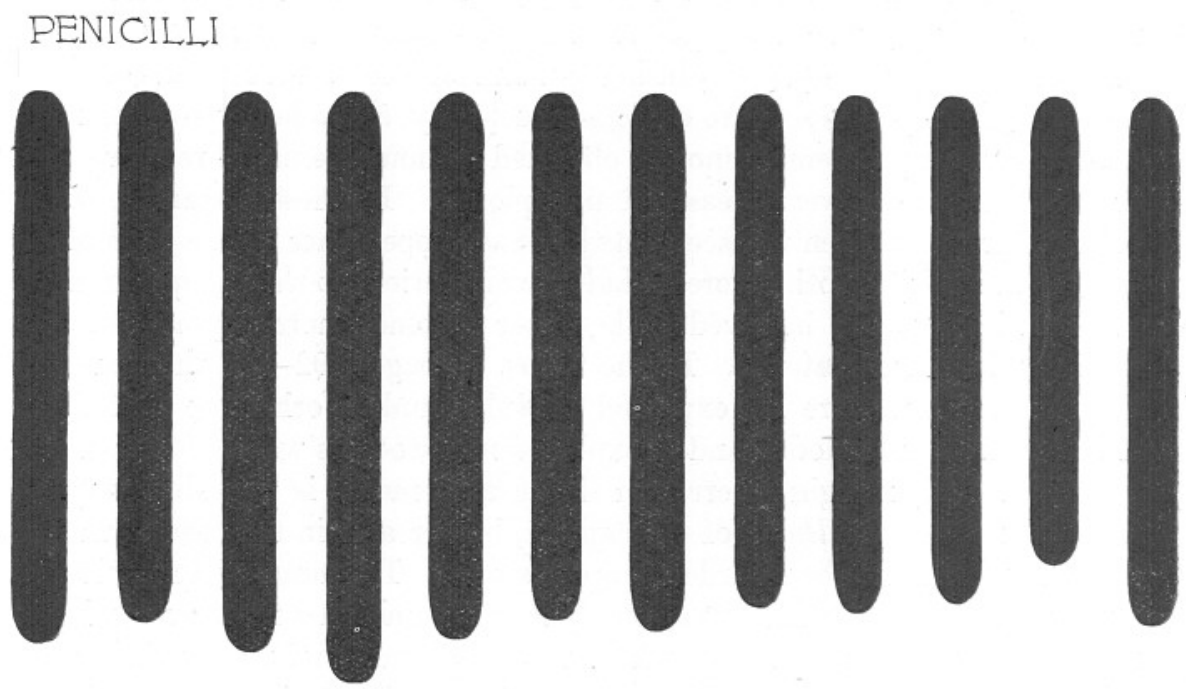

Text-Fig. 2.-Diagrams illustrating the average size of the capsules of the penicilli in the acontia of twelve specimens of Sagartia elegans. In this figure, and in Text-Figs. 3, $5-7$, and 9-10, each diagram represents the average length and breadth of the capsules of a given type from a single tissue of a single individual anemone; these figures are further explained in the text. A conventional shape has been adopted for all these diagrams, and all are drawn to the same scale ; they are not intended to illustrate the actual shapes of the various capsules, and they are slightly more approximate than the figures given in the tables at the end of the paper.

rosea, roseoides, and miniata-ornata), and the figures given are based on measurements of 30 capsules of each pattern from each specimen. These numbers are not large, but the measurements take a long time to make, and it is consequently impracticable to make them on a very extensive scale.

In the acontia of certain Actinians two types of nematocyst are plentiful. The first of these, a penicillus, is a capsule bearing a short, stout thread, barbed like a bottle-brush; examples of this type are illustrated in Plate I, Figs. 5-7, and in Text-Fig. 1. In this type there is sometimes a slender terminal thread, which may be long or may be 
short and wisp-like, at the end of the " bottle-brush" (as in Pl. I, Fig. 6, and in Text-Fig. 1, F); in other cases there is no terminal thread. The minor varieties within the type are characteristic of different species. The second type usually but not invariably possesses a smaller capsule, but a very much longer and more slender thread, the basal portion of which is either somewhat enlarged or bears well-developed barbs, or both ; this is known as a spirula, and is illustrated in Plate I, Figs. 2 and 3, and in Text-Fig. 1. Both of these types occur in S. elegans.

The figures for $S$. elegans are given in Table I on page 192; and in Text-Figs. 2 and 3 the average sizes of the capsules are represented graphically. From these figures it can readily be seen that the average

\section{SPIRULAE}

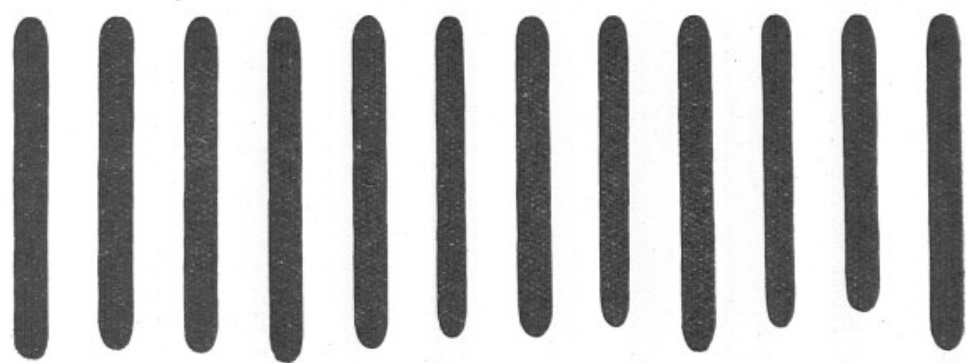

Text-Fig. 3.-Diagrams illustrating the average size of the spirulæ in the acontia of twelve specimens of Sagartia elegans-the same specimens as those from which the penicilli represented in Text-Fig. 2 were taken.

length of the capsule varies considerably from one specimen to another, but not within very wide limits. In these figures the diagrams are arranged in a graded series, so that the one representing the capsules of the largest specimen used is on the left, and that representing those of the smallest is on the right. From this it is evident that there is no strict relation between the size of the individual and the average size of its nematocysts. Text-Fig. 4 gives the maximum and minimum sizes of penicilli which were found in six of the twelve specimens, instead of the average.

\section{B. Connection between the Size of the Animal and the Size of the Nematocysts.}

The second point to be ascertained was how far, within a single stable species, the size of the nematocysts changes as the animal grows larger. It is impossible to tell the age of an anemone from its size, since size in these animals depends on the amount of food recently received, and not 
upon age. But in a viviparous form one can at least distinguish newborn young from older individuals. The species chosen for this purpose was Cereus pedunculatus, and measurements were made from two new-born young and from 5 adult specimens forming a graded series from a small to a very large one. The acontia were used again here, and measurements were made from 30 examples of each of the two types of capsule contained therein. The figures are detailed in Table II on page 192, and the result is represented graphically in Text-Fig. 5, the diagrams being arranged in order of size of the specimens from which the capsules were taken; the diagram representing those of the largest

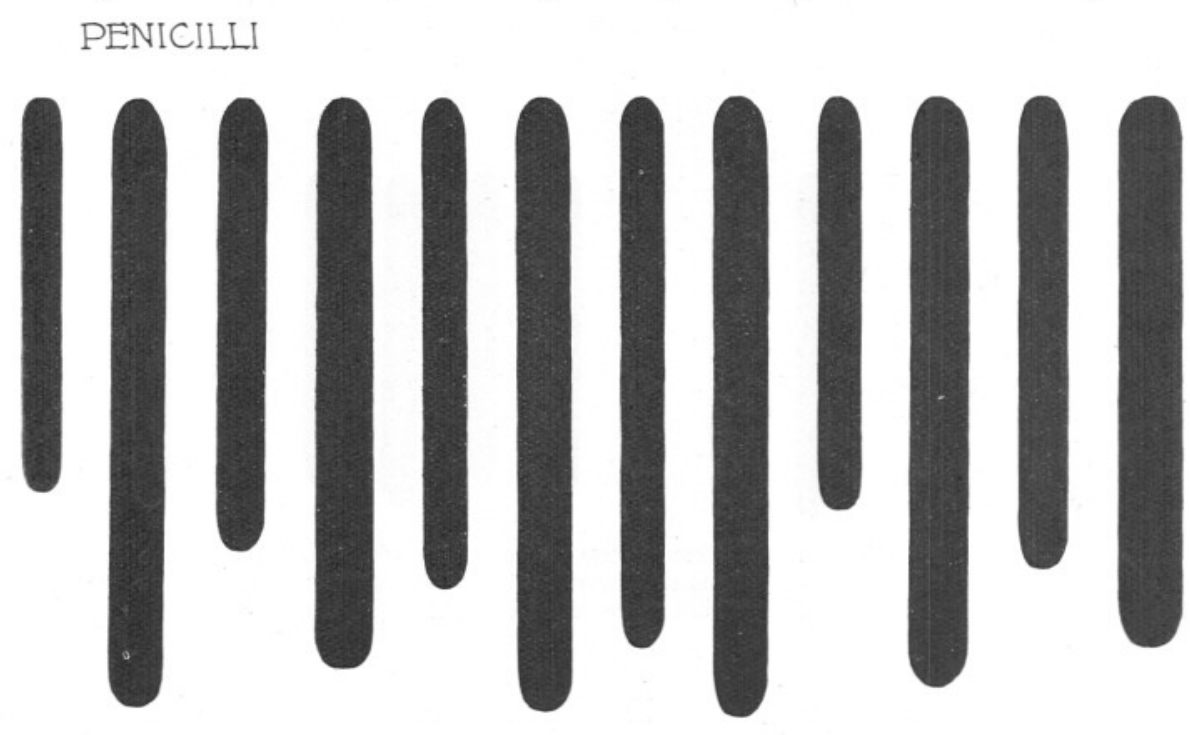

Text-Fig. 4.-Diagrams illustrating the maximum and minimum sizes of penicillus found in the acontia of six specimens of Sagartia elegans. The diagram on the extreme left refers to the same specimen as the one next to it; and so on, in pairs.

specimen is on the left. From this it will be seen that although the nematocysts of the new-born young are distinctly smaller than those of the adults of any size (and this was confirmed by further measurements from 4 other new-born young not detailed here), the size varies relatively little between the five adults, although these represent extremely different sizes of animal, No. 1 being many times the bulk of No. 5. Nor does the nematocyst-size increase regularly with the body-size.

\section{The Nematocysts in the Acontia of the Species of Sagartia.}

The third stage in the investigation was to find out in what manner nematocysts vary in a given tissue from one species of a genus to another, 
the genus Sagartia being used as a test-case. The acontia again were used, and nematocysts from three specimens of each Sagartian species were studied. By this time it had been realised that 20 measurements of any one type of capsule are enough to give a sufficient idea of the range
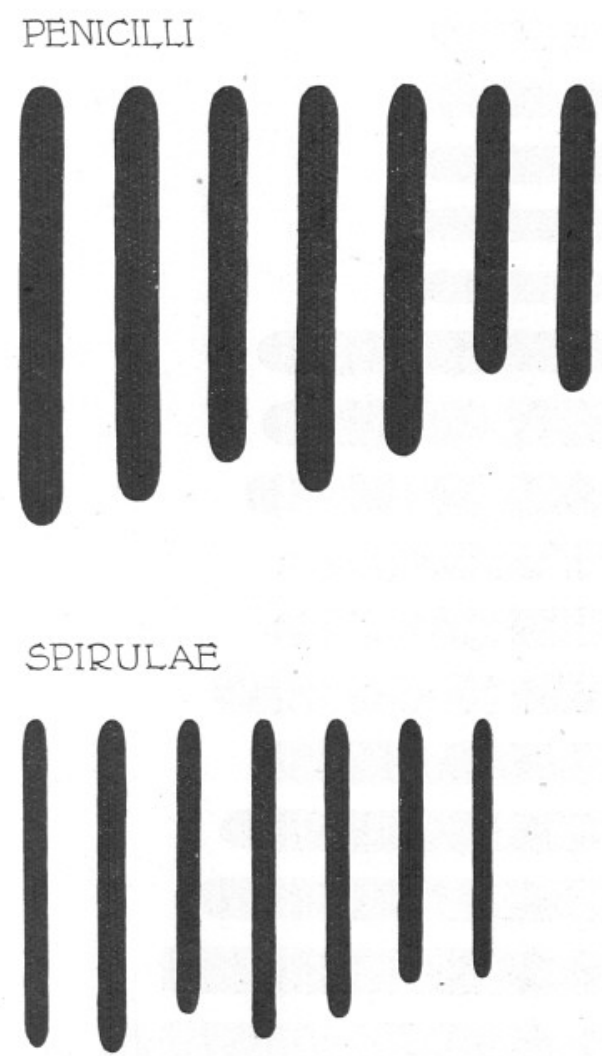

Text-Fig. 5.-Diagrams showing the average size of the penicilli and spirulæ in the acontia of seven specimens of Cereus pedunculatus. The diagrams are arranged in order of size of the anemone from which they were taken; that representing the capsules from the largest specimen is on the left. The two disgrams on the right represent capsules from new-born specimens.

of variation. In the measurements above recorded for $S$. elegans the average is very little different if calculated from the first 20 capsules measured, than if calculated from the whole 30 . Consequently in the observations recorded from this point onward, the figures are taken from measurements of 20 specimens of each kind of capsule, except 
in cases where for some special reason a smaller number only was practicable.

The figures relating to 4 species of Sagartia are recorded in Table III

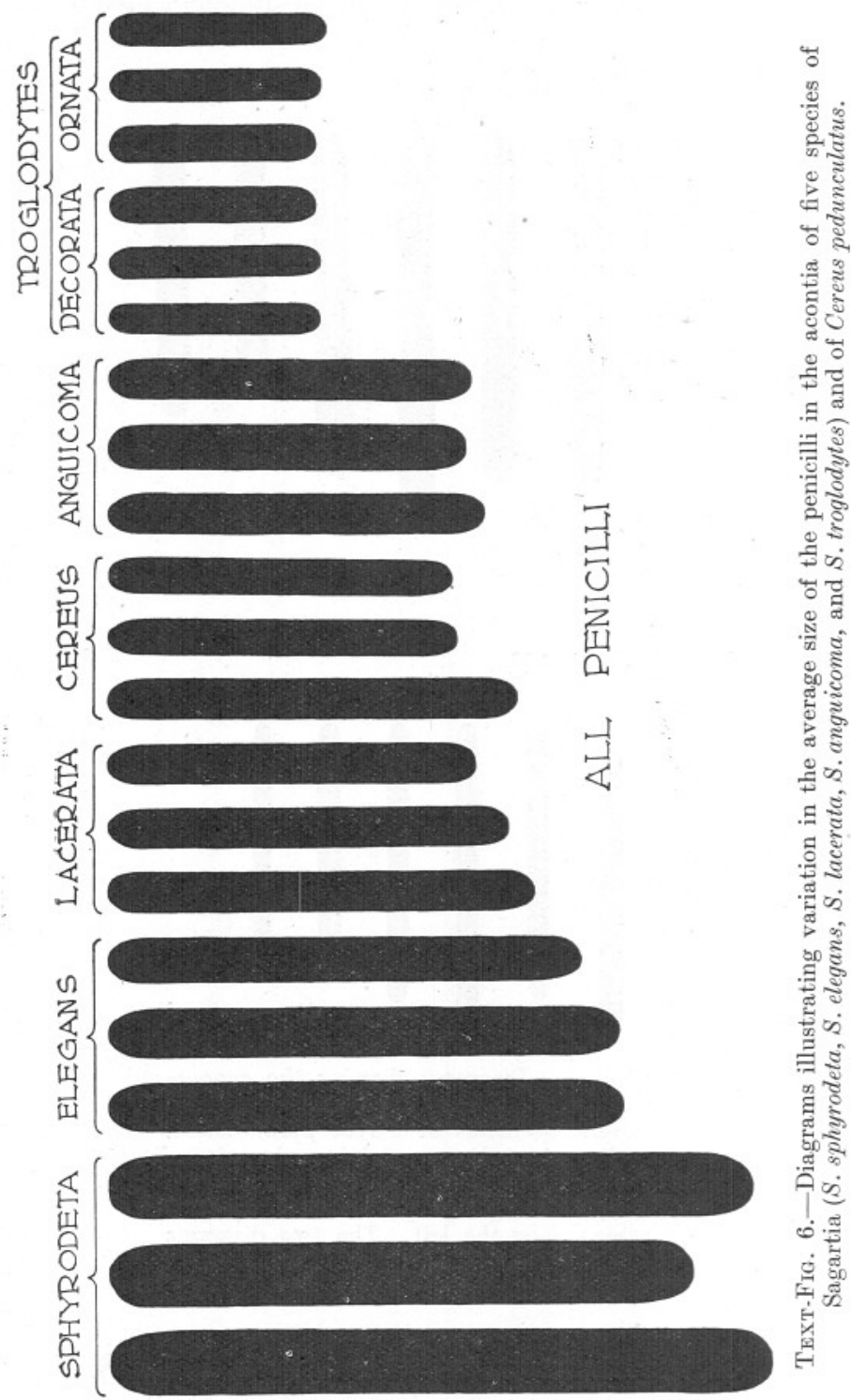

on page 193, and the average sizes of the capsules are indicated by diagrams in Text-Figs. 6 and 7 ; these latter include also Sagartia elegans and Cereus pedunculatus (which is very closely related to the Sagartias). 
From Fig. 6 it will be clear that the penicilli of Sagartia sphyrodeta (a small species) outstrip those of all others in size, and that the penicilli of S. troglodytes (both varieties) are much the smallest. There would therefore be no difficulty in separating individuals of $S$. troglodytes from those of $S$. sphyrodeta, in a mixed collection, on the strength of these capsules; nor, indeed, would there be much difficulty in separating one of these species from any others, given well-grown specimens. If, however, one were to attempt the same feat with a mixed batch of S. lacerata. S. anguicoma, and Cereus, it would be quite another matter. These could, of course, be sorted out on other grounds; but from the

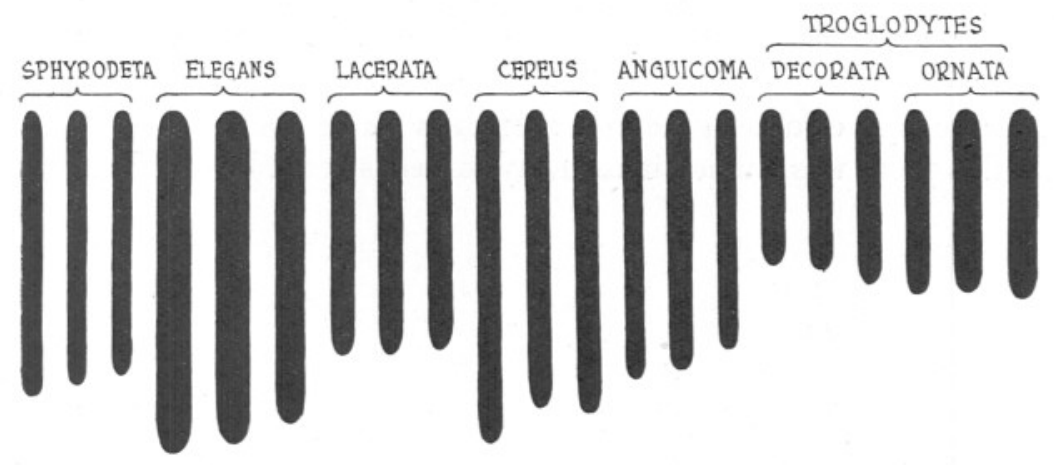

\section{ALI SPIRULAE}

Text-Fig. 7.-Diagrams illustrating the average size of the spirulæ in the acontia of the same specimens as those from which the penicilli represented in TextFig. 6 were taken.

penicilli of their acontia they could not, since the range of variation in one would overlap the range in another, the size being distinctly similar in all. In order to make this still clearer, I made an additional series of measurements of the penicilli of a specimen of each of these species, and I measured also those of two specimens of $S$. elegans, measuring in this case 100 of each, so that curves might be drawn from the measurements. The result is shown in Text-Fig. 8, from which it may be seen that the curves for $C$. pedunculatus and S. anguicoma (extremely distinct species) are very similar; so are those for $S$. lacerata and a small specimen of $S$. elegans, which again are very different in other respects. In this particular figure the curves for $S$. anguicoma $+C$. pedunculatus are separated by a gap from those for $S$. lacerata + small $S$. elegans ; but the gap between the small and the large $S$. elegans is greater. Moreover, it may be stated that by choosing one's specimens carefully these gaps could be filled in, and a graded series of curves produced, though the curves for the other species would hardly reach up to the level of the curve for the 
large $S$. elegans, since this species does really tend to have larger penicilli than the others. But it must be evident from the contemplation of these curves that it would be quite unsafe to attempt to distinguish the species involved on the basis of the size of the penicilli of their acontia. Even if it be true that the capsules of each tend to occupy a given range of size, the ranges for the several species are very close to one another.

An important point which is demonstrated by the above table is that in all the species of Sagartia, as well as in Cereus, there are both penicilli and spirulæ in the acontia; and the former are larger than the latter.

\section{The Nematocysts in the Acontia of other Genera.}

It was next desired to ascertain in what manner the nematocysts occur in the acontia of other genera of anemones which possess these organs, and this point was studied in as many forms as could be obtained alive.

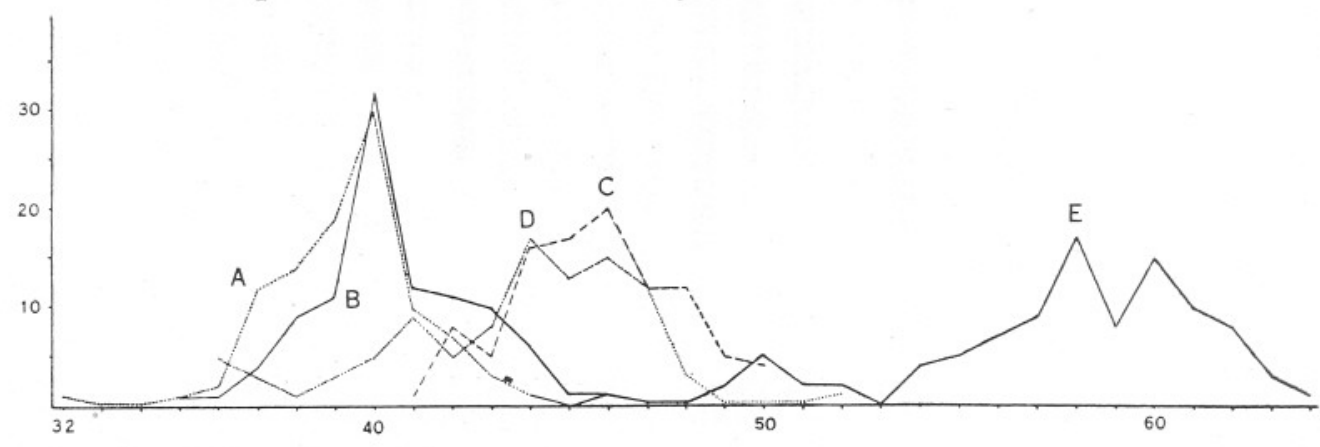

Text-Fig. 8.-Curves illustrating variation in the length of the penicilli of the acontia in specimens of three species of Sagartia and in Cereus pedunculatus. Each curve is plotted from measurements of 100 capsules. The numbers along the abscissa represent the lengths of the capsules in $\mu$; those along the ordinate represent the number of capsules of each length (to the nearest whole number) in each 100 measured. A, Sagartia anguicoma; B, Cereus pedunculatus; C, S. lacerata; D, S. elegans (small specimen); E, S. elegans (large specimen).

The result is detailed in Table IV on page 194, and in Text-Figs. 9 and 10. From these observations several facts emerge. The most important is that in the genera Phellia, Diadumene, and Aiptasia the acontia contain both penicilli and spirulæ in abundance, whereas in all the other genera spirulæ alone are present. No genus which. I have studied possesses penicilli only. This confirms the idea which has been gained from other sources, that all the genera with spirulæ only are closely related, and that Diadumene and Aiptasia are more or less closely related to each other, but show less affinity to the other series of forms. As to Phellia, it is a genus of obscure standing, which I will deal with more fully in another paper. Another point which becomes clear is that in the genera with 
spirulæ only (except Metridium) these are of very similar dimensions all the way through (see also Text-Fig. 9), and therefore their size is not of great value for purposes of identification.

The details of the nematocysts in these forms vary from one species to another-most distinctive are the large spirulæ of Metridium senile, which are unlike any other capsules I have seen. In these, the capsule itself is long, the thread is very long, and its specialised basal part, which is slender where it leaves the capsule, gradually widens to a maximum, then ceases abruptly ; this part is sometimes more than twice as long as the capsule. In the penicilli there is sometimes a slender terminal thread, which may be quite short, on the end of the "bottle-brush" portion (Aiptasia, Diadumene, Sagartia sphyrodeta), in other cases little or no trace of any such thread. Such differences, in some cases, are probably characteristic of species only; in others they perhaps characterise genera.

\section{E. The Nematocysts of Tissues other than Acontia.}

Finally, a short study was made of nematocysts occurring in tissues other than acontia, and in anemones possessing no acontia. In the latter, special attention was paid to acrorhagi, which, like acontia, are special stinging-batteries. I should have liked to extend this section of the work much further than time allowed.

The tables relating to this section of the work (Tables V to VII) will be found on pages 195-197. The points which may be deduced from them are as follows :-

(1) In Anthopleura ballii and A. thallia the acrorhagi contain a special type of nematocyst not found, so far as I know, elsewhere in the body. To what type these capsules belong I am not certain, but I think that in $A$. thallia, at least, they may be spirocysts of a particular kind, and not nematocysts at all.

(2) Bunodactis verrucosa has the same nematocysts in the "acrorhagi" as in the rest of the body-wall; the acrorhagi are therefore not special stinging-batteries in this case, but come under the heading of " pseudo-acrorhagi."

(3) In Peachia the prevalent nematocysts in the ectoderm of columnwall and tentacles, and the epithelium of the throat, are spirulæ of identical type, but of slightly different sizes. In the mesenterial filaments, however, there are three very distinct kinds of capsule ; one is a penicillus of a curious kind, one a large capsule of special type, with the basal part of the long thread very little differentiated (probably a modified spirula); the third an ordinary spirula. It is curious that the same general distribution of types occurs in the tissues of Anthopleura ballii, a form very different from Peachia. 
(4) In Phellia gausapata both penicilli and spirulæ occur in the epithelium of column, tentacles, and throat, as well as in the acontia; those of the acontia are unlike the rest, and minor variations appear from one tissue to another.

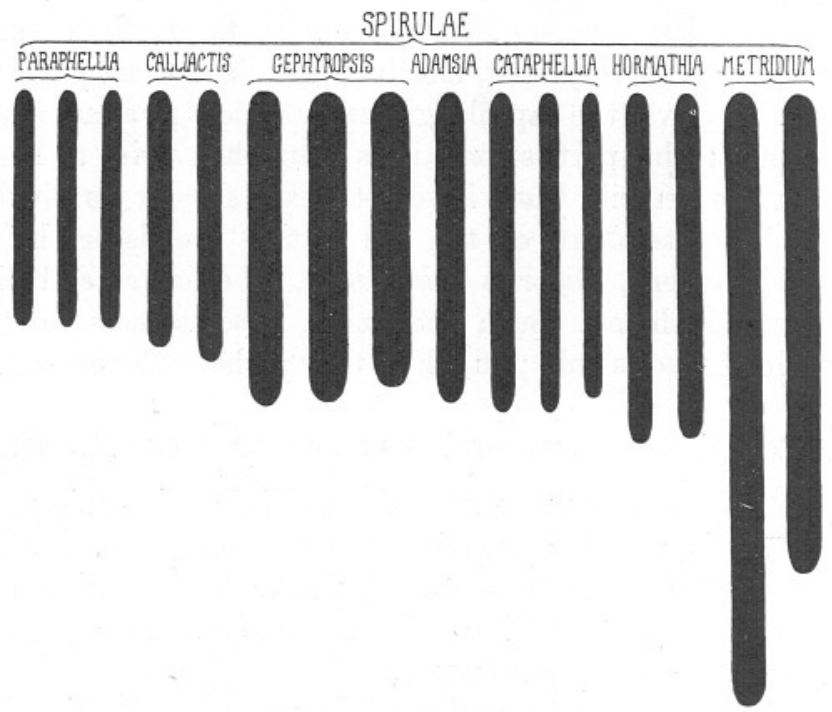

Text-Fig. 9.-Diagrams illustrating the average size of the spirulæ in the acontia of anemones of several genera.

\section{F. Other Data.}

There has been discussion as to whether the capsule of a nematocyst is larger before explosion than afterwards. I have made a certain number of measurements on exploded and unexploded cysts of the same kind, from the same tissue and usually from the same sample; the results are given in Table VIII.

This table includes both spirulæ and penicilli, and these from more than one tissue. In all cases there is a diminution of volume after the explosion, although sometimes it is very slight. I have very few data to offer with regard to the effect of reagents on the size of the capsule. In a specimen of Peachia triphylla I measured a few capsules of each of the three types which occur in the mesenterial filaments, some in the fresh condition, others after fixation in formalin.

$\begin{array}{ccc}\text { Type. } & \begin{array}{c}\text { Average Size } \\ \text { before Fixation. }\end{array} & \begin{array}{c}\text { Average Size } \\ \text { after Fixation. }\end{array} \\ 1 . & 24 \cdot 8 \times 4.2 \mu & 24 \cdot 8 \times 4 \cdot 0 \mu \\ 2 . & 46 \cdot 0 \times 5 \cdot 2 \mu & 46 \cdot 1 \times 5 \cdot 4 \mu \\ 3 . & 26.5 \times 3.9 \mu & 26 \cdot 0 \times 3 \cdot 7 \mu\end{array}$


In this instance, therefore, the fixation made no appreciable difference. I believe, however, that spirit affects the capsule more than formalin, and that nematocysts in sections are sometimes very considerably shrunken.

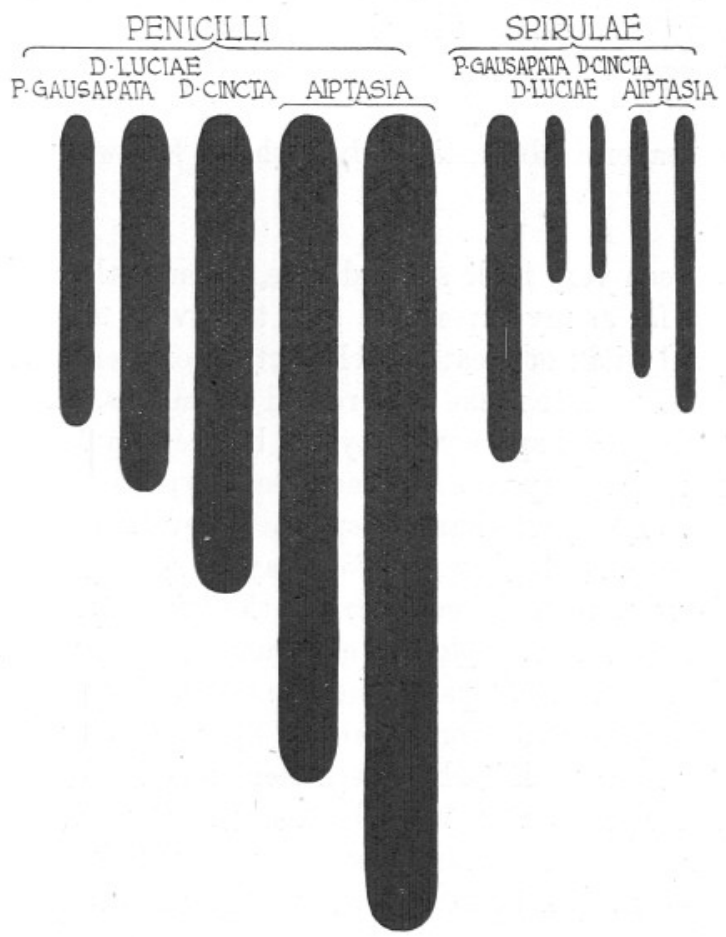

Text-Frg. 10.-Diagrams illustrating the average size of the penicilli and spirulæ in the acontia of Phellia gausa. pata, Diadumene lucia, D. cincta, and Aiptasia couchii.

\section{SUMMARY AND CONCLUSIONS.}

The cnidæ or explosive capsules of the Actiniaria comprise two distinct kinds.

(1) Spirocysts (Pl. I, Figs. 1 and 4). Thin-walled capsules with a thread which is closed at the end, and which bears spirals but no barbs. They stain readily with acid fuchsin, but the capsular content does not stain. Found in the tentacles and peristome only, in most species; in other tissues exceptionally. The spiral bands on the thread swell up in sea-water, and on contact with foreign bodies spread out into a network of strands; the thread is therefore adhesive, and may not be poisonous. The thread, prior to evagination, is coiled in a neat spiral within the capsule. 
(2) Nematocysts (Pl. I, Figs. 2, 3, 5-7, and Text-Fig. 1). Thick-walled capsules with a thread which is often open at the end and normally bears barbs. They typically stain with methylene blue, and the capsular content often becomes stained. Widely distributed in the tissues. Poisonous and penetrating. The thread, prior to evagination, may be variously arranged within the capsule.

The present paper deals particularly with the following points :-

\section{(1) Spirocysts.}

These have been very little studied here, because their distribution is limited, and as far as my experience goes they vary a good deal in size in the individual, and not greatly in character from genus to genus. The only suggestion I wish to make with regard to them is, that the ordinary and well-known type of spirocyst may not be the only kind in existence, and that there may be capsules intermediate in type between nematocysts and spirocysts. I suspect that the special capsules in the acrorhagi of certain species (e.g. Anthopleura thallia) may be spirocysts of an unusual kind, and I have seen in the ectoderm of the lower part of the body of Sagartia anguicoma and S. troglodytes enormous oval capsules of a peculiar sort. These have a thin collapsible wall, a stout and apparently unarmed thread which, before explosion, is coiled up spirocyst-wise within the capsule; they stain with fuchsin (although less deeply than ordinary spirocysts), and I think they must be a form of spirocyst. Moreover, although I have not studied this point in detail, I think that nematocysts are more variable in their action towards methylene blue than is generally supposed.

\section{(2) Nematocysts.}

With regard to these capsules, it is evident that two general patterns of cyst are widely distributed among Actinians. These two types, the penicillus and the spirula (described on pp. 178-179, and figured in Pl. I, and Text-Fig. 1) are easily distinguished from one another, although each contains varieties; and their distribution among the genera is of taxonomic importance. In one and the same tissue of an anemone there may be found spirulæ only, or both penicilli and spirulæ may be present together (possibly penicilli alone occur in certain cases). Furthermore, there may be present, for instance, two varieties of spirulæ as well as penicilli. Again, one or more of these kinds of capsule may be present in great quantity, others being more or less scarce (see note on p. 177). The following data refer to majority-forms only.

A. In the acontia of those Actiniaria studied which possess them, the nematocysts occur in two fashions; in the first, the acontia contain 
spirulæ only, in the second they contain both spirulæ and penicilli in abundance (i.e. there are 2 majority-forms of capsule).

B. Among the forms examined, the species belonging to a single genus have the same type or types of capsule in the acontia throughout, although the details may vary. Different genera, however, are in some cases sharply distinguished from one another by the nature of the nematocysts in their acontia; in other cases this is not so.

C. In Phellia gausapata, a species containing both penicilli and spirulæ in its acontia, both of these types occur in other tissues as well. In Peachia and in Anthopleura ballii, the prevalent capsules are spirulæ throughout most of the tissues, but in the mesenterial filaments three types, including penicilli, occur.

D. The size of the nematocysts in the acontia is useful in some cases as a specific distinction. This applies to Sagartia troglodytes and S. sphyrodeta, which are separable from the other British Sagartias on the basis of the size of the penicilli in their acontia.

E. In other cases the size of the capsules in one species is so nearly similar to that in another, that no distinction of the two forms is possible on the basis of this character. This applies to the penicilli of Sagartia anguicoma, S. lacerata, Cereus pedunculatus, and in lesser degree to those of S. elegans.

F. The size of the nematocysts in the acontia is sometimes very uniform from one genus to another, and in such cases gives very little help for generic determinations. This applies to Adamsia, Calliactis, Gephyropsis, Paraphellia, Hormathia, and Cataphellia, a closely related series of forms, all possessing spirulæ only in their acontia.

G. The variation in size of the capsules within a species is indicated by an example in Text-Figs. 2-4.

$H$. The size of the animal has not very much effect on the size of the nematocysts, except in extreme cases (Text-Figs. 2, 3, 5, and Tables I and II).

The general conclusion which may be drawn from the above data is that the distribution of different types of capsule may be very important in dealing with generic (and perhaps family) distinctions; and that the size of the capsule is useful as a specific character in certain cases, but useless in others. A good example of the ease with which genera are in some cases separable in this way is the case of Metridium and Diadumene. The young of $M$. senile and the adult of $D$. cincta, although perfectly distinct, are sufficiently similar in colour and facies to be confused with one another by an inexperienced observer. In the acontia of the Metridium, however, there are large spirulæ of a peculiar type, in abundance; whereas in those of the Diadumene both spirulæ and penicilli 
abound; and it is not difficult to make a preparation which will reveal these facts.

It is therefore evident that, as in the case of every other character connected with Actinian morphology, the nematocysts provide valuable diagnostic features in some cases and not in others; and this emphasises once more that in dealing with such animals the species cannot be understood unless the whole of the characteristics of the organism, and not a single series of features, be taken into account.

Carlgren has maintained for many years that no description of an Actinian is complete unless it includes details of the nematocysts, and that we cannot construct a final classification until we know enough about their occurrence in the group. He has provided measurements of the capsules in his own descriptions for some time. I am glad, as a result of the above study, to express my agreement with Carlgren in this matter, especially as I did not hold this view originally.

It is more difficult to deal with the nematocysts from preserved than from fresh material, because, although dissociated preparations can easily be made, one mostly sees the capsules unexploded or damaged, and it is not always possible to tell exactly to what type they may belong. As the number of types present is a factor often more important than the size, it is advisable to procure fresh material wherever possible.

In the various tables given on pages 192-198, the maximum and minimum dimensions which occurred among the capsules measured, as well as the average size, are stated. This gives a better idea of the situation than if one of these series of data only be quoted. Carlgren in his descriptions usually quotes the range; personally I should prefer the average, since it is my impression that the majority of capsules are of sizes not very far from the average, and that although it is useful to know the maximum and minimum, these are less significant than the average.

The reason why acontia have been so much used in this paper is that it was thought probable that in these special stinging organs, if anywhere, differences of diagnostic value would appear. I think the result justifies this idea. Probably the state of affairs in the acontia gives a key to that in the rest of the tissues--if we may judge by Phellia gausapata.

Since the above work was finished, Carlgren has kindly sent me particulars of a similar study, not yet published, which he has made on Actinian acontia. He has observed as I did, that in Hormathia, Calliactis, Paraphellia, Adamsia, and Gephyropsis there are nematocysts of one type only in the acontia; and to my list he adds the genera (mostly non-British) Actinauge, Phelliactis, Paracalliactis, Chondrophellia, 
Allantactis, Cricophorus, Stephanauge, Acraspedanthus, and Phelliogeton. Carlgren finds also the two types of capsule in the acontia of Sagartia (including Thöe), Phellia, Cereus, Diadumene and Aiptasia (with allied forms), and adds to this list Artemidactis, Choriactis, Parathöe, Sagartiogeton, Andvakia, and Isophellia. Moreover, in two peculiar genera (Kadosactis and Sagartiomorphe) he has observed penicilli only in the acontia; if these alone are present in quantity we have here a third type which I have not seen myself.

These investigations re-open the question of the classification of the anemones with acontia. I do not propose to discuss this subject in detail at present, but am willing to modify the scheme which I suggested in 1920, in the light of new knowledge. A provisional scheme which would meet with the views of both Carlgren and myself would be as follows.

1. Diadumenidæ, as defined by Carlgren, 1924, page 234. Acontia with both penicilli and spirulæ.

2. Aiptasiidæ, as defined by Carlgren, 1924, page 237. Acontia with both penicilli and spirulæ.

3. Metridiidæ. Including the Metridiidæ and Chondractiniidæ as defined by me in 1920, pages 526 and 533 (but omitting Sagartiomorphe and the Aiptasia group). For forms possessing spirulæ only, in the acontia ; base and basilar muscles; mesenteries not divided into macro- and microcnemes; usually six or about six pairs of perfect mesenteries. Cinclides present or not. Sphincter mesoglœal. Primary mesenteries often sterile.

4. Sagartiidæ. Including Sagartiidæ and Choriactidæ of my 1920 paper. The acontia possess both penicilli and spirulæ in abundance. Base and basilar muscles present; mesenteries not divided into macro- and microcnemes, usually more than six pairs perfect. Cinclides present as a rule. Sphincter mesoglœal. Primary mesenteries typically fertile.

5. Carlgren suggests the possible addition to these of new families, Kadosactidæ (for Kadosactis and Sagartiomorphe) and Acraspedanthidæ (for Acraspedanthus and Phelliogeton). These forms I do not know personally, so cannot yet form an opinion.

6. Phelliidæ. I hope to deal with this family shortly, in a separate paper.

7. Forms with no base or basilar muscles must perhaps (certainly according to Carlgren) be classified separately. I will return to this later. 


\begin{tabular}{|c|c|c|c|c|}
\hline $\begin{array}{l}\text { Number, variety } \\
\text { and locality } \\
\text { of specimen. }\end{array}$ & $\begin{array}{l}\text { Diameter } \\
\text { of base } \\
\text { of specimen } \\
\text { used. }\end{array}$ & $\begin{array}{c}\text { Type of } \\
\text { Nematocyst. }\end{array}$ & $\begin{array}{c}\text { Range of } \\
\text { variation in size. }\end{array}$ & \\
\hline \multirow{2}{*}{$\begin{array}{l}\text { 1. venusta } \\
\text { (Valencia) }\end{array}$} & \multirow{2}{*}{$2 \cdot 1 \mathrm{~cm}$} & Penicilli & $48-56 \times$ & \\
\hline & & & & \\
\hline \multirow{2}{*}{$\begin{array}{l}\text { 2. venustoides } \\
\text { (Plymouth) }\end{array}$} & \multirow{2}{*}{$1.6 \mathrm{~cm}$} & Penicilli & $40-57 \times 4-6 \mu$ & $51.6 \times 4.9 \mu$ \\
\hline & & Spirulæ & $29-35 \times 2.6-3.5 \mu$ & \\
\hline \multirow{2}{*}{$\begin{array}{l}\text { 3. roseoides } \\
\text { (Valencia) }\end{array}$} & \multirow{2}{*}{$2 \cdot 6 \mathrm{~cm}$} & Penicilli & & $\times 5 \cdot 1 \mu$ \\
\hline & & Spiru & & \\
\hline \multirow{2}{*}{$\begin{array}{l}\text { 4. miniata } \\
\text { (Plymouth) }\end{array}$} & \multirow{2}{*}{$2 \cdot 8 \mathrm{~cm}$} & Penicilli & $-6 \mu$ & $5 \cdot 3 \mu$ \\
\hline & & Spirt & & \\
\hline \multirow{2}{*}{$\begin{array}{l}\text { 5. venusta } \\
\text { (Plymouth) }\end{array}$} & \multirow{2}{*}{$1 \cdot 1 \mathrm{~cm}$} & Penic & $6 \mu$ & $.9 \mu$ \\
\hline & & Spiru & 24 & \\
\hline \multirow{2}{*}{$\begin{array}{l}\text { 6. nivea } \\
\text { (Plymouth) }\end{array}$} & \multirow{2}{*}{$2 \cdot 1 \mathrm{~cm}$} & Penic & $6-6 \mu$ & $5 \cdot 4 \mu$ \\
\hline & & Spirt & $-4.5 \mu$ & \\
\hline \multirow{2}{*}{$\begin{array}{l}\text { 7. rosea } \\
\text { (Valencia) }\end{array}$} & \multirow{2}{*}{$2 \mathrm{~cm}}$. & Peni & 50 & $5.5 \mu$ \\
\hline & & Spin & $29-8$ & $3 \cdot 5 \mu$ \\
\hline \multirow{2}{*}{$\begin{array}{l}\text { 8. nivea } \\
\text { (Valencia) }\end{array}$} & \multirow{2}{*}{$2 \cdot 7 \mathrm{~cm}$} & Penic & $6-6.5 \mu$ & $5 \cdot 5 \mu$ \\
\hline & & Spir & $28 \cdot 6$ & $34 \cdot 0$ \\
\hline \multirow{2}{*}{$\begin{array}{l}\text { 9. miniata } \\
\text { (Valencia) }\end{array}$} & \multirow{2}{*}{$1.0 \mathrm{~cm}$} & Peni & $4 \cdot 6-6 \mu$ & $5 \cdot 1 \mu$ \\
\hline & & & & $3 \cdot 4 \mu$ \\
\hline \multirow{2}{*}{$\begin{array}{l}\text { 10. venustoides } \\
\text { (Valencia) }\end{array}$} & \multirow{2}{*}{$1.9 \mathrm{~cm}$} & Pen & $42-5$ & \\
\hline & & Spirı & $\cdot 6-4 \mu$ & \\
\hline \multirow{2}{*}{$\begin{array}{l}\text { 11. niveoides } \\
\text { (Valencia) }\end{array}$} & \multirow{2}{*}{$2 \cdot 6 \mathrm{~cm}$} & Penic & $46-58 \times 5-6 \mu$ & $54 \cdot 1$ \\
\hline & & Spirulæ & $7 \times 3-4 \mu$ & \\
\hline \multirow{2}{*}{$\begin{array}{l}\text { 12. miniata } \\
\text { (Plymouth) }\end{array}$} & \multirow{2}{*}{$2 \cdot 7 \mathrm{~cm}$} & Penicilli & $56-63 \times 4 \cdot 6-6 \cdot 6 \mu$ & $59 \cdot 8$ \\
\hline & & Spirulæ & $32-38 \times 3-4 \mu$ & \\
\hline
\end{tabular}

\section{TABLE II.}

\begin{tabular}{|c|c|c|c|c|}
\hline $\begin{array}{l}\text { Number } \\
\text { of } \\
\text { specimen. }\end{array}$ & $\begin{array}{l}\text { Diameter } \\
\text { of expanded } \\
\text { tentacular } \\
\text { crown. }\end{array}$ & $\begin{array}{c}\text { Type of } \\
\text { Nematocyst. }\end{array}$ & $\begin{array}{c}\text { Range of } \\
\text { variation in size. }\end{array}$ & Average size. \\
\hline \multirow{2}{*}{1} & \multirow{2}{*}{$4.1 \mathrm{~cm}$} & Penicilli & $40-48 \cdot 6 \times 4-5 \mu$ & $44.5 \times 4.5 \mu$ \\
\hline & & Spirulæ & $29-36 \times 2 \cdot 4-3.4 \mu$ & $33.6 \times 2 \cdot 7 \mu$ \\
\hline \multirow{2}{*}{2} & \multirow{2}{*}{$3 \cdot 2 \mathrm{~cm}$} & Penicilli & $38-44 \times 4-5 \mu$ & $41.9 \times 4 \cdot 3 \mu$ \\
\hline & & Spirulæ & $30-38 \times 2 \cdot 4-3 \cdot 4 \mu$ & $33.9 \times 2.9 \mu$ \\
\hline \multirow{2}{*}{3} & \multirow{2}{*}{$2 \mathrm{~cm}}$. & Penicilli & $33-42 \times 3 \cdot 8-5 \cdot 4 \mu$ & $38.2 \times 4 \cdot 1 \mu$ \\
\hline & & Spirulæ & $28-33 \times 2 \cdot 2-3 \mu$ & $30.2 \times 2.5 \mu$ \\
\hline \multirow{2}{*}{4} & \multirow{2}{*}{$1.7 \mathrm{~cm}$} & Penicilli & $36-46 \times 3 \cdot 6-5 \mu$ & $40 \cdot 8 \times 4 \cdot 2 \mu$ \\
\hline & & Spirulæ & $29-36 \times 2 \cdot 4-3 \mu$ & $32.7 \times 2.6 \mu$ \\
\hline \multirow[t]{2}{*}{5} & \multirow{2}{*}{$1 \cdot 1 \mathrm{~cm}}$. & Penicilli & $34-42 \times 3 \cdot 6-4 \cdot 6 \mu$ & $37 \cdot 4 \times 4 \cdot 0 \mu$ \\
\hline & & Spirulæ & $28-35 \times 2-3 \mu$ & $30 \cdot 6 \times 2 \cdot 6 \mu$ \\
\hline
\end{tabular}




$\begin{array}{ccccc}\begin{array}{c}\text { Number } \\ \text { of } \\ \text { specimen. }\end{array} & \begin{array}{c}\text { Diameter } \\ \text { of expanded } \\ \text { tentacular } \\ \text { crown. }\end{array} & \begin{array}{c}\text { Type of } \\ \text { Nematocyst. }\end{array} & \begin{array}{c}\text { Range of } \\ \text { variation in size. }\end{array} & \text { Average size. } \\ 6 & \cdot 5 \text { cm. } & \text { Penicilli } & 25 \cdot 2-31 \cdot 2 \times 3 \cdot 2-4 \mu & 29 \cdot 1 \times 3 \cdot 6 \mu \\ & (\text { New born) } & \text { Spirulæ } & 25-30 \times 2-2 \cdot 6 \mu & 27 \cdot 1 \times 2 \cdot 3 \mu \\ 7 & \cdot 35 \text { cm. } & \text { Penicilli } & 30-35 \times 3 \cdot 4-4 \mu & 31 \cdot 2 \times 3 \cdot 6 \mu \\ & \text { (New born) } & \text { Spirulæ } & 23 \cdot 2-29 \times 2-2 \cdot 4 \mu & 26.5 \times 2 \cdot 2 \mu\end{array}$

TABLE III.

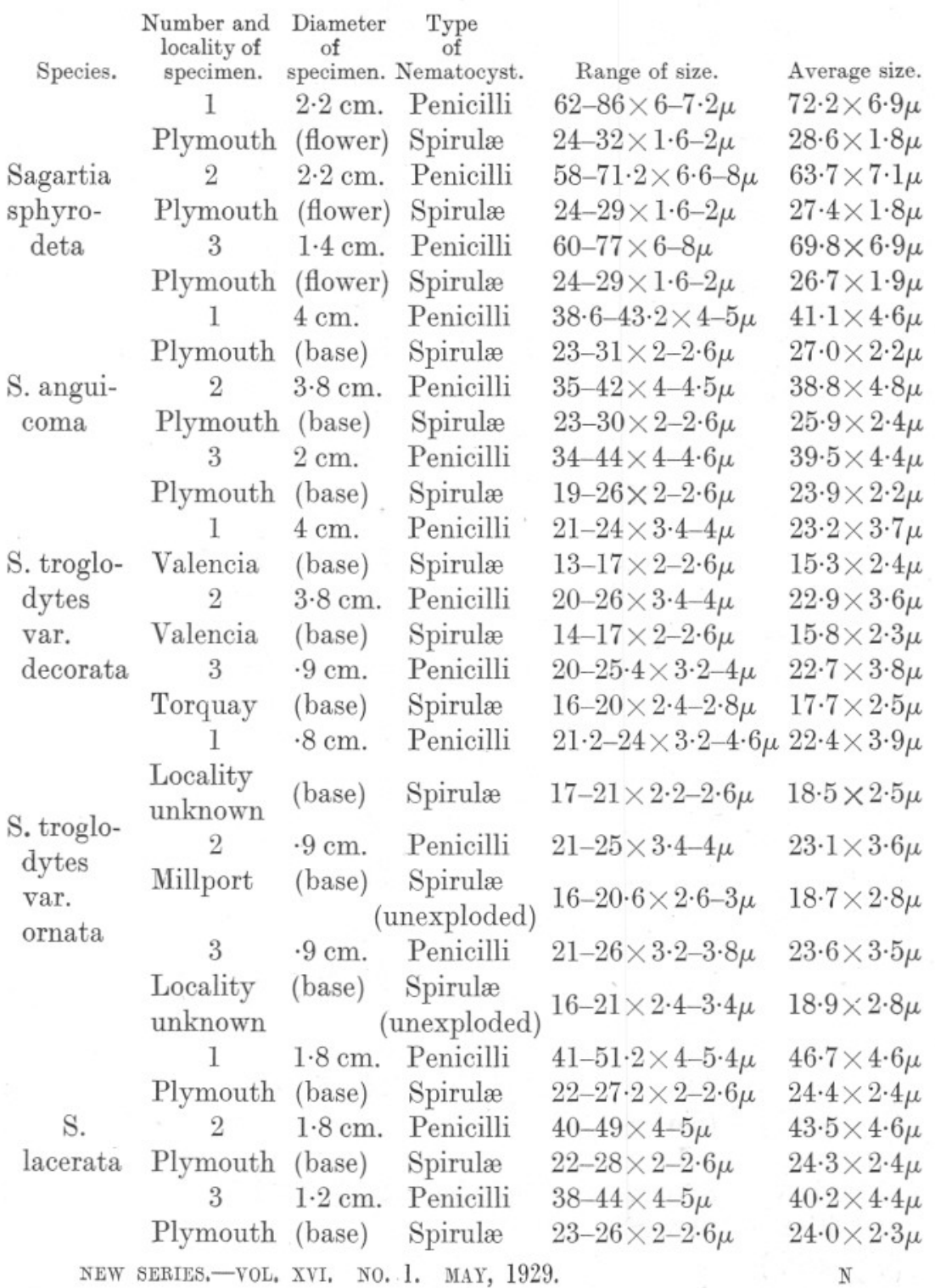


TABLE IV.

\begin{tabular}{|c|c|c|c|c|}
\hline \multirow{3}{*}{$\begin{array}{l}\text { Species } \\
\text { and } \\
\text { locality. }\end{array}$} & Number and & & & \\
\hline & $\begin{array}{l}\begin{array}{c}\text { size of } \\
\text { specimen. } \\
1\end{array}\end{array}$ & $\begin{array}{l}\text { of } \\
\text { Nematocyst. }\end{array}$ & Range of size. & Average size. \\
\hline & $\begin{array}{l}2 \cdot 8 \mathrm{~cm} \\
\text { (base) }\end{array}$ & Spirulæ & $22-26 \times 2-2 \cdot 6 \mu$ & $24 \cdot 2 \times 2 \cdot 2 \mu$ \\
\hline \multirow{5}{*}{$\begin{array}{l}\text { Paraphellia } \\
\text { expansa } \\
\text { (Plymouth) }\end{array}$} & 2 & & & \\
\hline & $\begin{array}{l}2.8 \mathrm{~cm} . \\
\text { (base) }\end{array}$ & Spirulæ & $22-26 \times 1 \cdot 8-2 \mu$ & $23.8 \times 2 \cdot 0 \mu$ \\
\hline & $\begin{array}{c}3 \\
\text { slightly }\end{array}$ & & & \\
\hline & $\begin{array}{l}\text { smaller } \\
\text { than } 1 \text { and } 2\end{array}$ & Spirulæ & $22-26 \times 1 \cdot 8-2 \cdot 4 \mu$ & $23 \cdot 9 \times 2 \cdot 0 \mu$ \\
\hline & (base) & Spirulæ & $30-35 \cdot 2 \times 2-2 \cdot 6 \mu$ & $32.5 \times 2.3 \mu$ \\
\hline \multirow{5}{*}{$\begin{array}{l}\text { Cataphellia } \\
\text { brodricii } \\
\text { (Salcombe) }\end{array}$} & $\begin{array}{c}1 \cdot 3 \mathrm{~cm} . \\
2\end{array}$ & & & \\
\hline & $\begin{array}{l}1.3 \mathrm{~cm} . \\
\text { (base) }\end{array}$ & Spirulæ & $30-37 \times 2-2 \cdot 4 \mu$ & $32 \cdot 6 \times 2 \cdot 1 \mu$ \\
\hline & 3 & & & \\
\hline & $\begin{array}{l}.9 \mathrm{~cm} . \\
\text { (base) }\end{array}$ & Spirulæ & $27-36 \times 2-2 \cdot 6 \mu$ & $31 \cdot 1 \times 2 \cdot 1 \mu$ \\
\hline & 1 & & & \\
\hline \multirow[t]{3}{*}{$\begin{array}{l}\text { Hormathia } \\
\text { coronata } \\
\text { (Plymouth) }\end{array}$} & $\begin{array}{l}2 \cdot 25 \mathrm{~cm} . \\
\text { (column) } \\
\quad 2\end{array}$ & Spirulæ & $33 \cdot 6-37 \times 2 \cdot 6-3 \mu$ & $35 \cdot 6 \times 2 \cdot 7 \mu$ \\
\hline & $\begin{array}{l}1 \cdot 3 \mathrm{~cm} . \\
(\text { column }) \\
\quad 1\end{array}$ & Spirulæ & $33-38 \times 2 \cdot 4-3 \mu$ & $35 \cdot 1 \times 2 \cdot 7 \mu$ \\
\hline & $\begin{array}{l}1.0 \mathrm{~cm} . \\
\text { (base) }\end{array}$ & Spirulæ & $28-43 \times 3 \cdot 2-4 \mu$ & $31.8 \times 3.7 \mu$ \\
\hline \multirow{3}{*}{$\begin{array}{l}\text { Gephyropsis } \\
\text { dohrnii } \\
\text { (Plymouth) }\end{array}$} & 2 & & & \\
\hline & $\begin{array}{c}1.0 \mathrm{~cm} . \\
\text { (base) } \\
3\end{array}$ & Spirulæ & $28-34 \times 3 \cdot 8-4 \cdot 6 \mu$ & $31.5 \times 4 \cdot 1 \mu$ \\
\hline & $\begin{array}{l}1.0 \mathrm{~cm} . \\
\text { (base) }\end{array}$ & Spirulæ & $28-32 \times 3 \cdot 2-4 \mu$ & $30 \cdot 3 \times 3 \cdot 8 \mu$ \\
\hline \multirow{2}{*}{$\begin{array}{l}\text { Adamsia } \\
\text { palliata } \\
\text { (Plymouth) }\end{array}$} & 1 & & & \\
\hline & $\begin{array}{c}4.8 \mathrm{~cm} . \\
\text { (flower) } \\
1\end{array}$ & Spirulæ & $28-35 \cdot 2 \times 2 \cdot 4-3 \mu$ & $31.7 \times 2.8 \mu$ \\
\hline $\begin{array}{l}\text { Calliactis } \\
\text { parasitica } \\
\text { (Plymouth) }\end{array}$ & $\begin{array}{l}8.5 \mathrm{~cm} . \\
\text { (flower) }\end{array}$ & Spirulæ & $24 \cdot 6-29 \times 2 \cdot 4-2 \cdot 8 \mu$ & $27 \cdot 4 \times 2 \cdot 6 \mu$ \\
\hline
\end{tabular}


THE NEMATOCYSTS OF SEA ANEMONES.

\begin{tabular}{|c|c|c|c|c|}
\hline $\begin{array}{l}\text { Species } \\
\text { and } \\
\text { locality. }\end{array}$ & $\begin{array}{l}\begin{array}{c}\text { Number and } \\
\text { size of } \\
\text { specimen. } \\
2\end{array} \\
2\end{array}$ & $\begin{array}{c}\text { Type } \\
\text { of } \\
\text { Nematocyst. }\end{array}$ & Range of size. & Average size. \\
\hline & $\begin{array}{l}8.5 \mathrm{~cm} . \\
\text { (flower) }\end{array}$ & Spirulæ & $24-28 \times 2 \cdot 4-2 \cdot 6 \mu$ & $26 \cdot 1 \times 2.5 \mu$ \\
\hline $\begin{array}{l}\text { Metridium } \\
\text { senile }\end{array}$ & $\begin{array}{l}1 \\
\text { column } 7 \mathrm{~cm} \\
\text { high (adult) }\end{array}$ & Spirulæ & $56-68 \times 3-3 \cdot 8 \mu$ & $62 \cdot 1 \times 3.5 \mu$ \\
\hline (Plymouth) & $\begin{array}{l}\text { base } \cdot 9 \mathrm{~cm} \text {. } \\
\text { across (young) }\end{array}$ & Spirulæ & $45 \cdot 2-52 \times 2 \cdot 6-3 \cdot 8 \mu$ & $48.4 \times 3.4 \mu$ \\
\hline $\begin{array}{l}\text { Phellia } \\
\text { gausapata } \\
\text { (Wick) }\end{array}$ & $\begin{array}{l}1 \\
\text { large } \\
\text { specimen }\end{array}$ & $\begin{array}{l}\text { Penicilli } \\
\text { Spirulæ }\end{array}$ & $\begin{array}{l}30-33 \times 3-3 \cdot 6 \mu \\
33-37 \times 3 \cdot 4-3 \cdot 8 \mu\end{array}$ & $\begin{array}{l}31.5 \times 3.3 \mu \\
34.8 \times 3.5 \mu\end{array}$ \\
\hline Diadumene & 1 & Penicilli & $31-42 \cdot 6 \times 4 \cdot 6-6 \mu$ & $38 \cdot 2 \times 5 \cdot 2 \mu$ \\
\hline $\begin{array}{l}\text { luciæ } \\
\text { (Plymouth) }\end{array}$ & $\begin{array}{l}.5 \mathrm{~cm} . \\
\text { (base) }\end{array}$ & $\begin{array}{l}\text { Spirulæ } \\
\text { (unexploded) }\end{array}$ & $15-19 \times 1 \cdot 6-2 \cdot 2 \mu$ & $16 \cdot 8 \times 2.0 \mu$ \\
\hline Diadumene & 1 & Penicilli & $44-52 \cdot 6 \times 5 \cdot 4-7 \cdot 4 \mu$ & $48.3 \times 6 \cdot 1 \mu$ \\
\hline $\begin{array}{l}\text { cincta } \\
\text { (Plymouth) }\end{array}$ & $\begin{array}{l}1 \cdot 4 \mathrm{~cm} . \\
\text { (base) }\end{array}$ & $\begin{array}{c}\text { Spirulæ } \\
\text { unexploded) }\end{array}$ & $15-18 \times 1 \cdot 4-2 \mu$ & $16.4 \times 1.7 \mu$ \\
\hline & 1 & Penicilli & $57-78 \times 5 \cdot 4-7 \cdot 4 \mu$ & \\
\hline $\begin{array}{l}\text { Aiptasia } \\
\text { couchii }\end{array}$ & (flower) & & & \\
\hline (Plymouth) & $\begin{array}{r}2 \\
1 \cdot 3\end{array}$ & Penicilli & $74-90 \times 6-8.4 \mu$ & $82.6 \times 7 \cdot 4 \mu$ \\
\hline & (column) & & & \\
\hline
\end{tabular}

\section{TABLE V.}

Species with Acrorhagi, etc.

1. Anthopleura ballii, a Valencia specimen. Diameter of flower $4.5 \mathrm{~cm}$. All capsules measured unexploded.

Tissue. Acrorhagi

Ectoderm of column wall Ectoderm of tentacle
Type of capsule.

Type 1. Form charac- $34-42 \cdot 6 \times 2 \cdot 2-3 \mu$ istic of the Acrorhagi

$\left.\begin{array}{l}\text { Type } 2 \\ \text { Type } 3\end{array}\right\}$ Spirulæ

Spirulæ

$22-26 \times 2-2 \cdot 6 \mu$ $16-21 \times 1 \cdot 9-2 \cdot 4 \mu$ $16-19 \times 2-2 \cdot 4 \mu \quad 16 \cdot 6 \times 2 \cdot 0 \mu$ Spirulæ $22-27 \cdot 2 \times 2-2 \cdot 6 \mu$ $23.5 \times 2.3 \mu$ $18.7 \times 2 \cdot 1 \mu$

Average size. $38.4 \times 2.7 \mu$ $24.5 \times 2.4 \mu$ 
Tissue.

Type of capsule.

Range of size.

Average size.

Mesenterial Type 1. Penicilli $16 \cdot 6-20 \times 3 \cdot 8-4 \cdot 6 \mu \quad 17 \cdot 9 \times 4 \cdot 4 \mu$

filament

Type 2. Large special kind

$33 \cdot 2-42 \times 4-4 \cdot 4 \mu \quad 39 \cdot 0 \times 4 \cdot 1 \mu$

Type 3. Spirulæ

$16-17 \times 2 \mu$

$16 \cdot 7 \times 2 \mu$

Epithelium of Spirulæ $28-31 \times 2 \cdot 6-3 \mu$ $29 \cdot 2 \times 2 \cdot 9 \mu$ throat

2. Anthopleura thallia, a Torquay specimen. Height of animal $3 \cdot 6 \mathrm{~cm}$. Capsules measured unexploded.

Tissue.

Type of capsule.

Range of size.

Average size.

Acrorhagi

Type characteristic of

Acrorhagi

(Spirocysts also are

$36 \cdot 6-45 \cdot 6 \times 4-5 \cdot 4 \mu \quad 40 \cdot 6 \times 4 \cdot 7 \mu$ present; so are

Spirulæ)

3. Bunodactis gemmacea, a Plymouth specimen. Diameter of column $1.5 \mathrm{~cm}$. Capsules measured unexploded.

Tissue. Type of capsule. Range of size. Average size.

$\begin{array}{clll}\text { Pseudo- } & \text { Type 1. Rod-like kind } & 25-41.6 \times 1-1.2 \mu & 31.0 \times 1 \cdot 1 \mu \\ \text { acrorhagi } & \text { Type 2. Spirulæ } & 11 \cdot 2-14 \times 1.6-2 \cdot 2 \mu & 12.8 \times 1.9 \mu \\ \text { Ectoderm of } & \text { Type 1. Rod-like kind } & 25 \cdot 2-38 \times 1-1.2 \mu & 32.3 \times 1.0 \mu \\ \text { column wall } & \text { Type 2. Spirulæ } & 12-15 \times 1.6-2 \mu & 13.2 \times 1.9 \mu\end{array}$

\section{TABLE VI.}

\section{Peachia.}

1. Peachia hastata. A Port Erin specimen. Total length (contracted) $2 \cdot 2 \mathrm{~cm}$. Capsules measured unexploded except in throat. Measured on one specimen except those of the tentacles, which were taken from another similar example.

\begin{tabular}{|c|c|c|c|}
\hline Tissue. & $\begin{array}{l}\text { Type of } \\
\text { Nematocyst. }\end{array}$ & Range of size. & Average size. \\
\hline $\begin{array}{l}\text { Epithelium of } \\
\text { throat }\end{array}$ & Spirulæ & $21-25 \times 2 \cdot 6-3 \cdot 6 \mu$ & $22 \cdot 7 \times 3 \cdot 2 \mu$ \\
\hline $\begin{array}{l}\text { Ectoderm of } \\
\text { column wall }\end{array}$ & Spirulæ & $13 \cdot 2-16 \times 2 \cdot 6-3 \cdot 4 \mu$ & $14.8 \times 2.8 \mu$ \\
\hline $\begin{array}{l}\text { Ectoderm of } \\
\text { tentacles }\end{array}$ & $\begin{array}{l}\text { Spirulæ } \\
\text { Spirocysts }\end{array}$ & $\begin{array}{l}18-25 \cdot 2 \times 2 \cdot 6-3 \cdot 6 \mu \\
18-24 \times 2 \cdot 4-3 \mu\end{array}$ & $\begin{array}{l}21 \cdot 1 \times 3 \mu \\
20 \cdot 2 \times 2 \cdot 8 \mu\end{array}$ \\
\hline $\begin{array}{l}\text { Mesenterial fila- } \\
\text { ments (measured } \\
\text { after fixation } \\
\text { in formalin) }\end{array}$ & $\begin{array}{l}\text { Type 1. Penicilli } \\
\text { Type 2. Large kind } \\
\text { Type 3. Spirulæ }\end{array}$ & $\begin{array}{l}16-18 \times 3 \cdot 8-4 \cdot 6 \mu \\
24-42 \times 5 \cdot 2-6 \cdot 6 \mu \\
20-27 \cdot 2 \times 3 \cdot 4-4 \mu\end{array}$ & $\begin{array}{l}16 \cdot 9 \times 4 \cdot 1 \mu \\
33 \cdot 7 \times 5 \cdot 8 \mu \\
24 \cdot 2 \times 3 \cdot 7 \mu\end{array}$ \\
\hline
\end{tabular}


Further measurements were made on 2 larger preserved specimens of P. hastata from Port Erin. I. Formalin specimen $5 \cdot 6 \mathrm{~cm}$. long. Filaments, Type 1 , range $17-19 \cdot 6 \times 4 \mu$, average $18.4 \times 4 \mu$; Type 2 , range $26-41 \times 4 \cdot 6-7 \cdot 4 \mu$, average $31 \cdot 4 \times 5 \cdot 4 \mu$. II. Spirit specimen $6 \cdot 5 \mathrm{~cm}$. long. Filaments, Type 1, range $20-22 \times 3-3 \cdot 8 \mu$, average $20 \cdot 8 \times 3 \cdot 3 \mu$.

2. Peachia triphylla. A Plymouth specimen. Total length (contracted) $4 \cdot 1 \mathrm{~cm}$. Capsules measured unexploded except in throat.

\begin{tabular}{|c|c|c|c|}
\hline & $\begin{array}{l}\text { Type of } \\
\text { Nematocyst. }\end{array}$ & Range of size. & Average size. \\
\hline $\begin{array}{l}\text { Epithelium of } \\
\text { throat }\end{array}$ & Spirulæ & $24-28 \times 3 \cdot 4-5 \mu$ & $26 \cdot 0 \times 4 \cdot 1 \mu$ \\
\hline $\begin{array}{l}\text { Ectoderm of } \\
\text { column wall }\end{array}$ & Spirulæ & \multicolumn{2}{|c|}{$15 \cdot 6-19 \cdot 6 \times 2 \cdot 2-3 \cdot 4 \mu 17 \cdot 7 \times 2 \cdot 6 \mu$} \\
\hline $\begin{array}{l}\text { Ectoderm of } \\
\text { tentacles }\end{array}$ & $\begin{array}{l}\text { Spirulæ } \\
\text { Spirocysts }\end{array}$ & $\begin{array}{l}19-28 \times 2 \cdot 2-3 \cdot 2 \mu \\
16-28 \times 3-3 \cdot 8 \mu\end{array}$ & $\begin{array}{l}23 \cdot 6 \times 2 \cdot 7 \mu \\
23 \cdot 1 \times 3 \cdot 2 \mu\end{array}$ \\
\hline $\begin{array}{l}\text { Mesenterial } \\
\text { filaments }\end{array}$ & $\begin{array}{l}\text { Type 1. Penicilli } \\
\text { Type 2. Large kind } \\
\text { Type 3. Spirulæ }\end{array}$ & $\begin{array}{l}23-27 \times 4-4 \cdot 6 \mu \\
42-50 \times 4-6 \mu \\
24-28 \times 3 \cdot 8-4 \mu\end{array}$ & $\begin{array}{l}24 \cdot 8 \times 4 \cdot 2 \mu \\
46 \cdot 0 \times 5 \cdot 2 \mu \\
26 \cdot 5 \times 3 \cdot 9 \mu\end{array}$ \\
\hline
\end{tabular}

TABLE VII

Phellia gausapata.

A large specimen from Wick, Caithness. Capsules measured unexploded except in acontia.

\begin{tabular}{|c|c|c|c|}
\hline $\begin{array}{l}\text { Tissue. } \\
\text { Acontia }\end{array}$ & $\begin{array}{l}\text { Type of } \\
\text { Nematocyst. } \\
\text { Penicilli } \\
\text { Spirulæ }\end{array}$ & $\begin{array}{l}\text { Range of size. } \\
30-33 \times 3-3 \cdot 6 \mu \\
33-37 \times 3 \cdot 4-3 \cdot 8 \mu\end{array}$ & $\begin{array}{l}\text { Average size. } \\
31.5 \times 3.3 \mu \\
34.8 \times 3.5 \mu\end{array}$ \\
\hline Ectoderm of & $\begin{array}{c}\text { Penicilli } \\
\text { (commonest form) }\end{array}$ & $14-18 \times 3 \cdot 2-4 \mu$ & $16.4 \times 3.5 \mu$ \\
\hline tentacles & $\begin{array}{l}\text { Spirulæ } \\
\text { Spirocysts }\end{array}$ & $\begin{array}{l}16 \cdot 6-21 \times 2-2 \cdot 4 \mu \\
14 \cdot 6-29 \times 2-4 \cdot 6 \mu\end{array}$ & $\begin{array}{l}19 \cdot 7 \times 2 \cdot 1 \mu \\
22 \cdot 9 \times 3 \cdot 3 \mu\end{array}$ \\
\hline $\begin{array}{l}\text { Ectoderm of } \\
\text { scapulus }\end{array}$ & Penicilli & $16-18 \times 3 \cdot 6-4 \mu$ & $16 \cdot 9 \times 3 \cdot 7 \mu$ \\
\hline $\begin{array}{l}\text { Ectoderm of } \\
\text { scapus (low } \\
\text { down) }\end{array}$ & $\begin{array}{l}\text { Penicilli } \\
\text { Spirulæ }\end{array}$ & $\begin{array}{l}17-20 \times 3 \cdot 8-4 \mu \\
14-17 \cdot 6 \times 3 \cdot 2-3 \cdot 8 \mu\end{array}$ & $\begin{array}{l}18 \cdot 1 \times 4 \mu \\
16 \cdot 3 \times 3 \cdot 5 \mu\end{array}$ \\
\hline $\begin{array}{l}\text { Epithelium of } \\
\text { throat }\end{array}$ & $\begin{array}{l}\text { Penicilli } \\
\text { Spirulæ }\end{array}$ & $\begin{array}{l}21 \cdot 2-25 \times 3 \cdot 8-4 \cdot 6 \mu \\
24 \cdot 6-29 \times 2-2 \cdot 6 \mu\end{array}$ & $\begin{array}{l}23.5 \times 4 \cdot 1 \mu \\
26 \cdot 8 \times 2 \cdot 2 \mu\end{array}$ \\
\hline
\end{tabular}




\section{TABLE VIII.}

\begin{tabular}{|c|c|c|c|c|}
\hline Species. & Tissue. & $\begin{array}{l}\text { Type of } \\
\text { capsule. }\end{array}$ & $\begin{array}{c}\text { Average size } \\
\text { before explosion. }\end{array}$ & $\begin{array}{l}\text { Average size } \\
\text { after explosion. }\end{array}$ \\
\hline $\begin{array}{l}\text { Paraphellia } \\
\text { expansa }\end{array}$ & Acontia & Spirulæ & $25.9 \times 2.4 \mu$ & $24 \cdot 2 \times 2 \cdot 2 \mu$ \\
\hline $\begin{array}{l}\text { Cereus } \\
\text { pedunculatus }\end{array}$ & Acontia & $\begin{array}{l}\text { Penicilli } \\
\text { Spirulæ }\end{array}$ & $\begin{array}{l}49 \cdot 5 \times 5 \cdot 6 \mu \\
36 \cdot 6 \times 3 \cdot 3 \mu\end{array}$ & $\begin{array}{l}44.5 \times 4.5 \mu \\
33.6 \times 2.7 \mu\end{array}$ \\
\hline $\begin{array}{l}\text { Peachia } \\
\text { hastata }\end{array}$ & $\begin{array}{l}\text { Epithelium of } \\
\text { throat }\end{array}$ & Spirulæ & $26 \cdot 1 \times 4 \mu$ & $22 \cdot 7 \times 3 \cdot 2 \mu$ \\
\hline & $\begin{array}{l}\text { Ectoderm of } \\
\text { column wall }\end{array}$ & Spirulæ & $14 \cdot 8 \times 2 \cdot 8 \mu$ & $14 \cdot 0 \times 2 \cdot 4 \mu$ \\
\hline \multirow[t]{2}{*}{$\begin{array}{l}\text { Peachia } \\
\text { triphylla }\end{array}$} & $\begin{array}{l}\text { Epithelium of } \\
\text { throat }\end{array}$ & Spirulæ & $27 \cdot 2 \times 4 \cdot 2 \mu$ & $26 \cdot 0 \times 4 \cdot 1 \mu$ \\
\hline & $\begin{array}{l}\text { Ectoderm of } \\
\text { column wall }\end{array}$ & Spirulæ & $17 \cdot 7 \times 2 \cdot 6 \mu$ & $16.4 \times 2.5 \mu$ \\
\hline $\begin{array}{l}\text { Calliactis } \\
\text { parasitica }\end{array}$ & Acontia & Spirulæ & $29 \times 2 \cdot 9 \mu$ & $27 \cdot 4 \times 2 \cdot 6 \mu$ \\
\hline \multirow[t]{2}{*}{$\begin{array}{l}\text { Phellia } \\
\text { gausapata }\end{array}$} & $\begin{array}{l}\text { Ectoderm of } \\
\text { tentacles }\end{array}$ & Penicilli & $16.4 \times 3.5 \mu$ & $14 \cdot 7 \times 3 \cdot 2 \mu$ \\
\hline & $\begin{array}{l}\text { Ectoderm of } \\
\text { scapulus }\end{array}$ & Penicilli & $16.9 \times 3 \cdot 7 \mu$ & $14 \cdot 8 \times 3 \cdot 2 \mu$ \\
\hline $\begin{array}{r}\text { Sagartia } \\
\text { elegans }\end{array}$ & Acontia & Penicilli & $67 \cdot 2 \times 6.9 \mu$ & $59 \cdot 8 \times 5 \cdot 7 \mathrm{~s}$ \\
\hline
\end{tabular}

\section{LITERATURE.}

Bedot, M., 1889. Observations sur les nématocystes. Arch. Sci. phys. nat. Genève, (3), 22, pp. 606-608.

Carlgren, O., 1900. Ostafrikanische Actinien. Jahrb. hamburg. wiss. Anstalt., Hamburg, 17, Beiheft 2, pp. 23-44; 7 pls., col.

Carlgren, O., 1921. Actiniaria, Pt. 1. Danish Ingolf-Expedition, Copenhagen, 5, 9, pp. 1-241 ; Pls. 1-4; text illust.

Carlgren, O., 1924. Actiniaria from New Zealand and its Subantarctic Islands. Vidensk. Medd. naturh. Fören. Kjœbenhavn, 77, pp. 179261 ; text illust.

Chun, C., Will, L., And KüHn, A., 1889-1916. Cœlenterata (Hohlthiere): H. G. Bronn's Klassen und Ordnungen des Tier-Reichs, 2, Abt. 2, Leipzig, pp. 1-538; Pls. 1-33; text illust.

Cú́not, L., 1907. L'Origine des nématocystes des Éolidiens. Arch. Zool. exp. gén., Paris, (4) 6, pp. 73-102 ; Pl. 3 ; text illust.

Glaser, O. C., and Sparrow, C. M., 1909. The physiology of nematocysts. J. Exp. Zool., Philadelphia, 6, p. 361. 
Gosse, P. H., 1860. Actinologia Britannica: A history of the British sea-anemones and corals, etc., London, 1860. (Note; published in parts as follows: pp. 1-160, 1858; pp. 161-352, and Preface, 1859 ; pp. 353-362, 1860.) Pp. $x l+362$; 11 pls., col.

HADZI, J., 1909. Über die Nesselzellwanderung bei den Hydroidpolypen. Arb. zool. Inst., Univ. Wien, 17, pp. 65-94 ; 2 pls. ; text illust.

Iwanzoff, N., 1897. Über den Bau, die Wirkungsweise und die Entwickelung der Nesselkapseln der Cœlenteraten. Bull. Soc. Nat. Moscou, (N.S.) 10, pp. 95-161 ; Pls. 3, 4. Ibid., pp. 323-355 ; Pls. 5, 6.

Jасовsонn, A., 1912. Die Nesselzellen. Arch. Naturgesch.; Berlin, 78, A, heft 8, pp. 111-142; 2 pls. ; text illust. (Also issued as Inaugural Dissertation.)

Lendenfeld, R. von, 1897. Die Nesselzellen der Cnidarier. Biol. Cbl., Leipzig, 17, pp. 465-485, 513-530.

Martin, C. H., 1914. A note on the occurrence of nematocysts and similar structures in the various groups of the animal kingdom. Biol. Cbl., Leipzig, 34, pp. 248-273 ; text illust.

Murbach, L., 1894. Beiträge zur Kenntnis der Anatomie und Entwickelung der Nesselorgane der Hydroiden. Arch. Naturgesch., Berlin, 60, Bd. 1, pp. 217-254; Pl. 12.

Murbach, L., 1896. Observations on the development and migration of the urticating organs of sea-nettles, Cnidaria. Proc. U.S. Nat. Mus., Washington, 18, pp. 733-740.

Naville, A., 1926. Notes sur les Eolidiens. Un Eolidien d'eau saumâtre. Origine des nématocystes, zooxanthelles et homochromie. Rev. suisse Zool. Genève, 33, pp. 251-289 ; text illust.

Schulze, P., 1922. Der Bau und die Entladung der Penetranten von Hydra attenuata Pallas. Arch. Zellforsch., Leipzig, 16, pp. 383-438; Pl. 19 ; text illust. (Note : contains good bibliography of literature on cnidæ.)

Stephenson, T. A., 1920-1922. On the classification of Actiniaria. I. Forms with acontia and forms with a mesoglœal sphincter. Quart. J. Micr. Sci., London, 64, 1920, pp. 425-574; 1 pl. ; text illust. II. Consideration of the whole group and its relationships, with special reference to forms not treated in Pt. I. Ibid., 65, 1921, pp. 493-576 ; text illust. III. Definitions connected with the forms dealt with in Pt. II. Ibid., 66, 1922, pp. 247-319.

Stephenson, T. A., 1928. The British Sea Anemones. Vol. I, London, Ray Society ; 14 pls., col. ; text illust.

Toppe, O., 1910. Untersuchungen über Bau und Funktion der Nesse1zellen der Cnidarier, Tl. 1. Zool. Jahrb., Anat., Jena, 29, pp. 19l280 ; Pls. 13-16. 
WEILL, R., 1923-1926. (A number of short papers on various aspects of Cœelenterate nematocysts) in C.R. Acad. Sci., Paris, 180, pp. 327, 474, 611, 772 (1925) ; ibid., 182, pp. 1244, 1357 (1926) ; ibid., 183, p. 154 (1926). C.R. Soc. Biol., Paris, 89, p. 1322 (1923) ; ibid., 92, pp. 507, 509, 512, 981 (1925).

WeILL, R., 1926. Existence, chez certains cœlentérés, d'une cnidome specifique, caractéristique de l'état larvaire. Interprétation des monocnidomes. Bull. Soc. zool. Fr., Paris, 51, pp. 254-260; text illust.

WILL, L., 1909. Über das vorkommen kontraktiler Elemente in den Nesselzellen der Cœlenteraten. Sitzber. naturf. Ges. Rostock, (N.F.) 1, pp. 33-52 ; 2 pls. ; text illust.

Wrlu, L., 1909a. Die Klebkapseln der Aktinien und der Mechanismus ihrer Entladung. Ibid., (N.F.) 1, pp. 65-102; 2 pls., col.

WiLl, L., 1910. Die sekretorischen Vorgange bei der Nesselkapselbildung der Cœlenteraten. Ibid., (N.F.) 2, pp. 7-47; text illust.

WILL, L., 1919. Die Volumenreduktion der Nesselkapseln bei der Explosion und infolge "Alterns." Anat. Hefte, Wiesbaden, 1 Abt., 57 pp. 483-545 ; 4 pls. ; text illust.

\section{PLATE I.}

Fic. 1.-A completely evaginated spirocyst from Tealia felina, very highly magnified. After Will, 1909a, Pl. 3, Fig. 4 (slightly modified). Here the spiral bands have partially disappeared, their substance having swelled and become drawn out into strands in places. Anastomosis has taken place between some of the strands.

FIg. 2.-An evaginated nematocyst (of the spirula type) from an acontium of Sagartia elegans. The long terminal part of the thread is not shown, and the barbs have fallen off, revealing clearly the spiral bands. The enlarged basal part is rendered wider than usual here by the medium employed (mercury medium; see text).

FIG. 3.-A partially evaginated nematocyst (spirula type) from an acontium of Hormathia coronata. The distal part of the thread is still inside the capsule. The individual barbs are not shown here, only the general effect produced; they are actually inserted in the manner shown in Fig. 7, but point the other way.

Frg. 4.-Spirocyst of Tealia felina, very highly magnified. After Will, 1909a, Pl. 3, Fig. 9. The thread is only partially evaginated. The spiral bands are clearly visible on the wide evaginated part; on the narrow portion which is not yet extruded the series of diagonal strokes represents the continuation of the spiral bands on the inner wall of this portion.

Fig. 5.-The capsule of an evaginated nematocyst (of the penicillus type) from an acontium of Sagartia sphyrodeta. Oc. 2, obj. 10.

FIG. 6.-The thread belonging to the capsule shown in Fig. 5, drawn to same scale. Slightly diagrammatic. The terminal portion of the thread is not shown, but was short and slender. The barbs were actually continued (though becoming more delicate) almost to the base of the thread, but were rendered barely visible in the lower part by the stain and medium employed (methylene blue used with potassium hydroxide and followed by mercury medium; see text). Oc. 2 , obj. 10.

FIG. 7.-Diagrammatic enlargement of the terminal part of the thick region of the thread from another nematocyst similar to that shown in Fig. 6. 

